\title{
A Glimpse Into School Self-Evaluation in Malaysia: Are We Doing The Right Things? Or Are We Doing the Things Right?
}

\author{
Mohd Izham Mohd Hamzah ${ }^{1} \&$ Hafizah Binti Mohd Tahir ${ }^{1}$ \\ ${ }^{1}$ Faculty of Education, Universiti Kebangsaan Malaysia, Selangor, Malaysia \\ Correspondence: Mohd Izham Mohd Hamzah, Faculty of Education, UniversitiKebangsaan Malaysia, 43600 \\ UKM Bangi, Selangor, Malaysia. E-mail: izham@ukm.my
}

Received: August 1, 2013

doi:10.5539/ass.v9n12p50
Accepted: August 16, 2013 Online Published: August 30, 2013

URL: http://dx.doi.org/10.5539/ass.v9n12p50

\begin{abstract}
The focus of this paper is on the policy and implementation of School Self-Evaluation (SSE) conducted in Malaysian schools. It begins by having an overall look on what school evaluation is including its definition, purposes, link to external evaluation and also instruments which are used throughout the world. It then traces the history of SSE in Malaysia. Next, it discusses the policy underlining the SSE as dictated by the Ministry of Education Malaysia. This paper further explores the reality behind the implementation of this form of internal evaluation whilst linking it with school inspection conducted by the Inspection Body under the Ministry of Education Malaysia. By doing so, it will also try to capture some of the SSE concepts which embody its implementation. Then, it analyses the manner of how SSE is done by highlighting some important issues that need to be dealt with accordingly by the relevant authorities. Finally, it concludes by discussing the future of SSE in Malaysia.
\end{abstract}

Keywords: school self-evaluation, school inspection, policy, implementation

\section{Introduction}

Malaysia is embarking on a mission of reaching Vision 2020 in order to become a fully developed nation by the year 2020. One of Malaysia's biggest and fundamental assets needed to achieve this vision is its human capital. Therefore the Ministry of Education (MOE) bears a lot of responsibilities in moulding Malaysia's desired human capitals (Malaysia, 2010). MOE's vision is to provide an equal opportunity for all Malaysian children to receive a quality education. It is one of the five outcomes that MOE aspires to achieve by the end of 2025: access, equity, unity and efficiency (Malaysia, 2012). In order to ensure all these desired outcomes are displayed in its school systems, MOE has to conduct various evaluations. One of the evaluation method used is school self-evaluation (SSE).

Thus, it is important to cast a critical look into its implementation in Malaysia in order to ensure that SSE plays its role effectively. An analysis of Malaysia's policy and implementation of SSE explored in this paper will perhaps reveal an interesting reflection to the MOE. Apart from that, an in-depth discussion is needed by exploring briefly the roles of the various key players in Malaysian education system. It is the aim of this paper to at least raise some issues that need to be considered seriously.

\section{What Is SSE?}

\subsection{Definition}

Throughout the years, SSE has indeed gained a lot of supporters worldwide claiming that it is vital in ensuring quality education with a strong recommendation by most researchers of the things to do and don't (Vanhoof et al., 2009; Schildkamp et al., 2009; MacBeath, 2006; Demetrious \& Kyriakides, 2012). SSE is considered as an attempt involving various changes made by the schools in order to ensure a better teaching and learning environment, improve students' academic achievement and also strengthen the schools' ability to implement those changes (Hopkins, 2005). It encompasses of changes done towards the schools' policy, structures, norms, concepts, habits and patterns of work (Lander \& Eckholm, 2005; Vanhoof et al., 2011; McNamara \& O'Hara, 2008). In fact, it requires the schools to play an active and autonomous role while involving themselves in the processes of improvement and building capacity (Bubb et al., 2007).

$\mathrm{SSE}$ adheres to a systematic and structured form of evaluation which relies on a range of evidence gathered from 
all the concerned stakeholders in the schools (Plowright, 2008). It involves a cycle of several activities such as setting the schools' direction, planning, evaluating and identifying various improvements steps (Hofman et al, 2009). MacBeath (2009) lists out several key elements that define what SSE is all about. One of them is schools themselves conduct an assessment in order to identify the quality and effectiveness of their functions and responsibilities. Thus, SSE is considered as an internal and formative evaluation which is based on a collection of evidence. Or in other words the schools have to base their judgments on all the evidence gathered to identify the effectiveness of the implementation of the schools' programs. The Office for Standards in Education, Children's Services and Skills (Ofsted) as the leading organisation in the implementation of SSE stresses that it is a reflection process by the schools on their own practice. SSE needs to be operated in a systematic and transparent manner in order to achieve its aims to improve the students' achievement and enhance the schools' professional and organizational learning (Ofsted, 2012).

\subsection{Purposes}

Most researchers agree that SSE is to aid the schools in improving the quality of education (MacBeath, 2006; Vanhoof et al., 2009; Schildkamp et al., 2009; Demetrious \& Kyriakides, 2012). For countries which practice SSE as part of their educational evaluation system, the purpose of SSE obviously differ from one another based on its individual needs and objectives (Recling 2004 in Penzer 2011). The most common purpose shared by most countries is perhaps striving for school improvement.

Hopkins (2005) defines school improvement as efforts constructed for the aim of increasing the students' academic achievement by putting emphasis, for example, on the teaching and learning process. It involves a lot of strategies in increasing the school's capacity to provide a quality education. MacBeath (2009) further points out that there are three key elements of SSE. It focuses on students' achievement, vision of education and values that exist in the school. In addition, Creemers \& Kyriakides (2012) stress that it is important to understand that the need for school improvement must be based on "effective practices that promote learning in children".

One of the strategies of school improvement is the implementation of SSE (Hopkins, 2005; MacBeath, 2009; Creemers \& Kyriakides, 2012). SSE works as a reflection process which will identify and analyze the schools' strengths and weaknesses. From those analysis school improvements strategies will be constructed. Nevertheless, Coe (2010) warns that a very well-planned SSE is vital in order for school improvement to take place. Thus all the relevant key players need to find the relevant and ideal solutions which are applicable to the requirements and needs of their respective schools.

\subsection{SSE and School Inspection}

In some countries, there are strong links between internal evaluation and external evaluation (Penzer, 2011; Sze, 2012). Both evaluation tools play a very influential part in determining the quality of education in the schools. The world known example of this is as practiced by OfSTED which has been integrating external and internal evaluation since 1990s (MacBeath, 2006). Malaysia, Hong Kong and Scotland are also among the countries which practice both internal and external evaluation.

In general, SSE serves as internal evaluation whereas school inspection functions as external evaluation. Obviously the biggest difference of both forms is internal evaluation is conducted by the schools themselves whereas external evaluation is usually done by the appointed inspection or supervision body (Vanhoof et al., 2010; Janssens \& Amelsvoort 2008).

hey do share some common characteristics. One of them is both put strong emphasis on the school heads' accountability in enforcing quality education in schools (Hofman et al., 2009). In addition, both adhere to a systematic process which collect plentiful of evidence based on the schools' performance. Among the information they need would be on students' academic achievement, quality of teaching and also leadership and management of the school heads (OfSTED, 2012; Inspectorate and Quality Assurance, 2010). Both evaluations are also interrelated because they form an important element of school improvement and reform policies in certain countries (McNamara et al., 2011). Furthermore, "SSE complements external evaluation in that the data gathered through self-evaluation feed into and confirm findings of the external evaluation exercise" (Jaffer, 2010).

\subsection{SSE Instruments}

In order for SSE to be conducted systematically, an evaluation instrument has to be constructed. Basically it will serve as a guideline or checklist on how SSE should be conducted. It should be easy to understand, use and suitable either on an ad hoc, spontaneous or ritual exercise (MacBeath, 2005). In general, some of the evaluation instruments are prepared by the inspection body and others are by the relevant authority. As ICT is no longer an 
uncommon thing in most parts of the world, the method of filling up the guideline or checklist has moved from paper and pen to online data entry. As SSE is a systematic evaluation, there is a time line for entering the data which differs from one country to the next. There are also various tools of evaluation which are used including analysis of quantitative data, individual interviews, group interviews, observations and spot checks (MacBeath, 2006).

England, for example, has begun to use the Self-Evaluation Form (SEF) in 2005 (Bubb et al, 2007) while Ireland introduced Looking At Our School (LAOS) in 2004 (McNamara \& O'Hara, 2012). An instrument for evaluating primary schools known as ZEBO was introduced in the Netherlands schools (Schildkamp, 2012) and Scotland uses an instrument known as How Good Is Our School? (HGIOS?) (Croxford \& Shaik, 2009). Malaysia is currently using Standard Quality of Education Malaysia (SQEM) 2010 as its SSE's instrument (Inspectorate and Quality Assurance, 2010).

\section{History of SSE in Malaysia}

In Malaysia, the implementation of SSE is closely related to MOE's inspection body which is known as Inspectorate of Schools. It is an inspection body whose jurisdiction is as stipulated in the Education Act 550 (Inspectorate and Quality Assurance, 2010). Although perhaps there are schools of thoughts which consider school inspection and self-evaluation as separate evaluation practices, Malaysia on the other hand, stresses on the strong link between both evaluations.

The history of SSE in Malaysia began in 2001 with the drafting of a SSE document (Inspectorate and Quality Assurance, 2008). Although in the beginning, the intention was for the document to act as guidance for the schools, it was rather complicated and difficult for the schools to complete them. The document was full with lengthy descriptions. During that time, the schools were being asked to conduct their SSE with the aid of the document, In 2003, realising the need to revise and improve SSE document, the Inspectorate of Schools worked on formulating a simpler version, SQEM-School, which aimed to work easily for the schools. Later in 2010, in order to cater for the Malaysian government's vision of embarking on the country's transformation programme, the Inspectorate of Schools again tediously re-examine and rewrite SQEM-School to better serve the schools. During this process, important stakeholders ranging from school heads, school teachers, representatives from various teachers' association and MOE's officers of various designations were involved.

Along with the revision of the SSE documents, the schools were also given a lot of information and training from time to time to equip them with the knowledge of implementing SSE. In addition, it is also important to note that SSE plays a huge role in achieving the Education NKRA. It began on 27 July 2009 when six National Key Result Areas (NKRAs) were announced by the Prime Minister of Malaysia. Basically each NKRA outlines objectives, outcomes and actions needed to be taken to achieve Vision 2020. One of the NKRAs is the Education NKRA. "The aspiration of the Education NKRA... is to improve student outcomes across Malaysia's school system and to enable access to quality education for all students" (Malaysia, 2010). Two of the four imperatives in achieving the aspiration are High Performing Schools and New Deals for Head Teachers and Principals. Both imperatives put a great deal of importance of SSE as indicators for their performance measurement.

\section{Moe's SSE Policy}

The underlying principal of SSE in Malaysia is the schools will be able to identify their strengths and weaknesses through their own reflections (Inspectorate of Schools, 2006). Thus, using those findings the schools will list out their development plans which should be realistic, achievable and most importantly cater to their own individual needs. This is because SSE allows the schools to determine their take off-value in every aspect of schooling. In addition it identifies every individual's needs and necessity, the development process of the students plus the school achievement in the academics, curriculum and the development of the students' characters and personality (IOS, 2007).

In order to ensure the implementation of SSE is conducted effectively, schools are required to use SQEM 2010 as their guidelines. This is where the school heads are expected to play their role in ensuring the systematic process of SSE. It is also important that the head teachers bear the responsibilities to lead a SSE committee in their respective schools. The aim of this committee is to ensure that SSE is conducted systematically. Apart from that SSE has to be done as a collaboration effort among all the school's community. The evaluation has to be based from abundance of data for examples, the students' academic results in both schools and public examinations, students' performance in co-curricular activities and also the quality of teaching and learning. All these must be documented for the verification of the Schools Inspectorates. 


\section{The Implementation of SSE in Malaysia}

As Malaysia practices internal evaluation and external evaluation, the Inspectorate of Schools has a very important role to play. MOE in its directive to all schools have instructed that all SSE results must be submitted to the Inspectorate of Schools. Therefore every year, the Inspectorate of Schools conducts an inspection in order to verify the SSE's scores which are determined by the school (Inspectorate and Quality Assurance, 2008). In principle, if a school remains at the same scores of achievement after the verification inspection, it indicates that the school has implemented its SSE properly. But if the school achievement scores decrease or increase after the verification inspection, this indicates a potential weakness or flaw in the implementation of SSE by the school.

In addition, the purpose of the verification inspection is also to identify the strength and weakness of SSE in schools. The inspection is conducted by analysing all the documents used by the school as evidence of their performance. Apart from that, observation of the teaching and learning process is also conducted at random. The School Inspectors will also conduct interview sessions with the school management and teachers in order to get a more comprehensive understanding. At the end, the complete findings will be submitted to the school and a copy of the report to the relevant authority. Most importantly, the Inspectorate of Schools will submit a full report regarding the status, strength and weakness of SSE's implementation to the Minister of Education. With the approval of the Minister of Education, the findings of the report will be shared within the authority in MOE for further improvement steps to be taken.

\section{SSE's Concepts}

The discussion which follow will look at MacBeath (2005) and Vanhoof and Petegem (2011) concept on SSE in relation to the implementation of SSE in Malaysia:

MacBeath (2005) in his article Self-evaluation Background, Principles and Key Learninglists seven important elements of SSE i.e. purpose, audience, framework, criteria and measures, process, tools and products. A look at Malaysia's SSE in relation with the seven elements reveals as follow:

1) Purpose: Why are the schools doing SSE? Basically there are two major purposes. Firstly as stated in SQEM (Inspectorate and Quality Assurance, 2010), schools are doing SSE in order to reflect on their strength, weakness and later identify their improvements initiatives. Secondly, in order to fulfil two of NKRA's Education requirement i.e. The New Deals for Head Teachers and Principals and High Performance Schools which basically aims on determining the performance of the schools.

2) Audience: Who is this for? Obviously the audience for the first purpose above is specifically for the consumption of the schools themselves, their relevant District Education Office and State Education Office. Whereas the second purpose is for MOE which will later be announcing to the public, not the details of the evaluation but just the overall performance of the schools concerned.

3) Framework: What is the best structure? All the schools must use SQEM 2010 in their evaluation process. In order to ensure the success of a well-implemented SSE, it is important that the schools have a comprehensive understanding of SQEM 2010. Therefore, each school is required to set up a committee chaired by its head teachers in order to ensure that the implementation of SSE is conducted systematically. The gathering of all the necessary evidence which will be proof to the schools' success and failures need to be documented accordingly. This is important because the School Inspectors will refer to the documented evidence during the verification inspection. In addition, the committee also needs to collaborate in determining the score for all the criteria in each standard.

4) Criteria and Measures: How are the schools to judge? Judgement is made using the five standards which are used to measure the schools' performance in SQEM 2010 as shown in Table 1. Each standard consists of a detailed explanation of critical criteria and each of them has descriptions which contain quality indicators as a guide in determining the score ranging from 1 to 6 . 
Table 1. Five standards of SQEM 2010

\begin{tabular}{ll}
\hline Standard 1 & Leadership and Vision \\
\hline Standard 2 & Organizational Management \\
Standard 3 & Curriculum, Co-curricular, Sports and Students' Affairs Management \\
Standard 4 & Learning and Teaching \\
Standard 5 & Students' Outcomes \\
\hline
\end{tabular}

Source: Inspectorate and Quality Assurance (2010:2)

5) Process: What do the schools do? Basically the schools need to conduct the evaluation beginning of each school year and has to be completed within a time frame given. The process of SSE done is similar to the framework.

6) Tools: What are the tools for the job? The schools are required to use SQEM 2010 as their tool of evaluation.

7) Product: What does the final product look like? The schools should have a list of their strength, weakness and improvements plans that they will undertake. Each school will also identify their level of achievement as follows:

Table 2. Level of achievement

\begin{tabular}{ll}
\hline Achievement Percentage & Level of Achievement \\
\hline $90-100$ & Outstanding \\
$80-89$ & Good \\
$60-79$ & Fair \\
$40-59$ & Satisfactory \\
$20-39$ & Weak \\
$0-19$ & Very weak \\
\hline
\end{tabular}

Source: Inspectorate and Quality Assurance (2010: 8)

Vanhoof and Petegem (2011) suggest that concept of SSE as a policy action. It stresses on the ideas that in order for SSE to take place, a suitable framework for implementing SSE based on seven basic principles. The first principle is the importance to be prepared to engage in systematic reflection. The schools need to be able to identify not only their strength but also their weaknesses. Therefore, they need to have an open attitude in conducting a critical and constructive reflection of their own performances. The second principle is the importance of shared objectives to be practiced in the schools. It is very important that the objectives of conducting SSE is fully understood by everybody concerned. It is also important for everybody to understand how the results of SSE will benefit them. By doing so, they will be able to give their full commitment in ensuring the success of SSE. Another principle is the importance of shared leadership as developing involvement within the school's community. Shared leadership in SSE has two elements: the school management plays the role as leaders and also the involvement of teachers in decision-making process.

The fourth principle is maintaining effective communication during SSE. Apart from ensuring the right information is delivered throughout the process of SSE, it also requires the right people and appropriate procedures to take place to guarantee effective communication. The next principle is creating supportive relationships and collaboration. The schools need to embrace supportive professional relationship among its community. It means that should be a strong support system among the teachers. The sixth principle is the importance of integrating self-evaluation into the current school policy. SSE should not be done in isolation. There should exist an integrated approach between SSE's objectives and activities with the other objectives planned by the school. The last principle is the necessity to be aware of the internal and external expectations regarding SSE. Apart from understanding the individual needs of the school, it is also important to take into considerations of the other stakeholders' views.

In addition, it seems that some of the seven principles of SSE as a policy action are embedded in the current 
practice of SSE in Malaysia. The SSE committee which is set up by the school and lead by the head teacher plays an important role in ensuring the school is prepared to conduct a systematic reflection. At the same time, this committee will create a supportive relationship and enhance collaboration whilst doing SSE. Shared leaderships perhaps is practiced when analysing the schools' performance. Nevertheless, for the rest of the principles, perhaps it is only fair to say that it requires research to be done in identifying whether it is practiced in SSE in Malaysia.

\section{Discussion}

\subsection{Collaboration Effort of the Schools}

The essence of SSE in Malaysia is for the schools to willingly admit their failures and embrace their strengths for the betterment of the students. The next stage of this reflection process leads by the school head teachers is for the schools to plan their realistic solutions. The consensus decisions are made by gathering information and feedback from the students, teachers and other important stakeholders. Apart from that, the schools' administration must also conduct continuous observation of the teaching and learning process. At the same time, the schools have to learn to collect the relevant data to support their claim and record them as evidence. All these must be embedded in the schools' daily activities (Inspectorate and Quality Assurance, 2010).

International research indicates that it is very important for each school to identify the reason why self-evaluation is conducted at the initial stage of the evaluation process (Janssens \& Amelsvoort, 2008). This is important so that every individual who is involved in this evaluation will have the same understanding, goal and target to achieve. Past research indicates that the quality of SSE is higher when everybody is well aware of their responsibilities and the importance of self-evaluation for their school (Davidsdottir \& Lisi, 2007; Vanhoof et al, 2009). Thus, perhaps it will be a futile effort if SSE is conducted without the schools really having a clear understanding why they are doing it.

It is commendable of MOE's good intention in acknowledging and rewarding the tremendous effort and roles played by the schools in ensuring the students' success. It is undeniable that the announcement of schools' ranking will definitely boost the schools' spirit to compete against each other (Malaysia, 2010). Nevertheless, it shouldn't stray away from the real intention of why SSE is conducted. Schools should not be too engrossed in aiming for high self-evaluation scores in order to be acknowledged nationwide and ignoring the essence of the evaluation. Or in other words, schools need to be realistic in conducting SSE in acknowledging their true colours.

SSE in Malaysia requires the head teachers to lead the evaluation process. In fact, SSE needs to be looked upon as a collaborative effort by all the teachers (Inspectorate and Quality Assurance, 2010). Perhaps the biggest task that the head teachers need to tackle is on how to convince the teachers that self-evaluation is not a waste of time and not an extra workload for them. This is rather alarming because international research shows that SSE bears a negative perception among some school staff (Meuret \& Morlaix, 2003; Hall \& Noyes, 2008). It is because it is looked upon as an extra burden to their work. Apart from that some claims that it adds emotional burden and pressures (Hall \& Noyes, 2009). Head teachers on the other hand have a more positive attitude with regards to SSE. This is perhaps due to their better perception on the link between SSE and the school's vision (Vanhoof et al., 2009). Therefore, head teachers play a very important role in the evaluation process (Emstad, 2011) not only to lead their schools but convince the rest of the other teachers SSE is vital for the school.

\subsection{Evidence of Progress}

Another interesting question that needs to be addressed is what is the exact proof through SSE that really justifies the schools' progress (Coe, 2010). Coe suggests that a well planned and high quality SSE system will be able to do the work. In the Malaysian context, schools are directed to use SQEM 2010 as their guidance. Although the process of drafting out SQEM 2010 involved a tedious process, it must be ready to explore any possibilities that further enhance its purposes. Currently, schools are required to key in their SSE's scores in an online portal within a stipulated time frame. At a glance the schools deal with numbers that are justified through a collaborative effort lead by the head teachers. At a deeper perspective, it should be looked upon as a conscious reflection done by the schools. Since the schools and Inspectorate of Schools are using the same instrument, it will be an advantage. International research suggests this condition will create a transparent communication between both parties regarding the quality of schools and it makes comparison easier (Janssens \& Amelsvoot, 2008).

\subsection{The Aftermath of SSE}

Another important issue that needs to be addressed is what do the schools really do when they have identified 
their area of weakness and plan for development (Bubb et al, 2008). Past research indicates that although some schools are able to conduct SSE effectively, they do still face problems on how to utilise the vast information that they have as the results of their evaluation (Devos \& Verhoeven, 2003; Schildkamp \& Visscher, 2009). What about the Malaysian schools? To date it is rather difficult to really determine how Malaysian schools are coping after their evaluation due to lack of research conducted on the matter.

\subsection{SSE Findings: The Inspectorate of Schools Versus the Schools}

According to the Inspectorate of Schools' Annual Report 2008, 56.4\% of 80 schools involved in the verification inspection showed that their evaluation scores were different from the results gathered by the School Inspectors (Inspectorate and Quality Assurance, 2008). It is also stated in the Annual Report 2009 that $57.94 \%$ of 107 schools involved in the verification inspection were facing the same problem (Inspectorate and Quality Assurance, 2009). In the Preliminary Report Malaysia Education Blueprint 2013-2025, there seems to be a difference between the School Inspectorates perception of quality of teaching and learning in schools compared to SSE conducted by the schools (Figure 1). For example, it is reported that $63 \%$ schools rank the teaching and practices in their schools as good and excellent compared to only $13 \%$ of the schools achieved these ranks based on the findings of the Inspectorate of Schools' inspection between 2009-2010 (Malaysia, 2012). Although perhaps not all the schools in Malaysia were able to be involved in this inspection, it still raises a few questions. SSE has been part of Malaysia's school systems for more than 10 years, but why are there still differences between the SSE's reports produced by the schools with the School Inspectors' assessment?

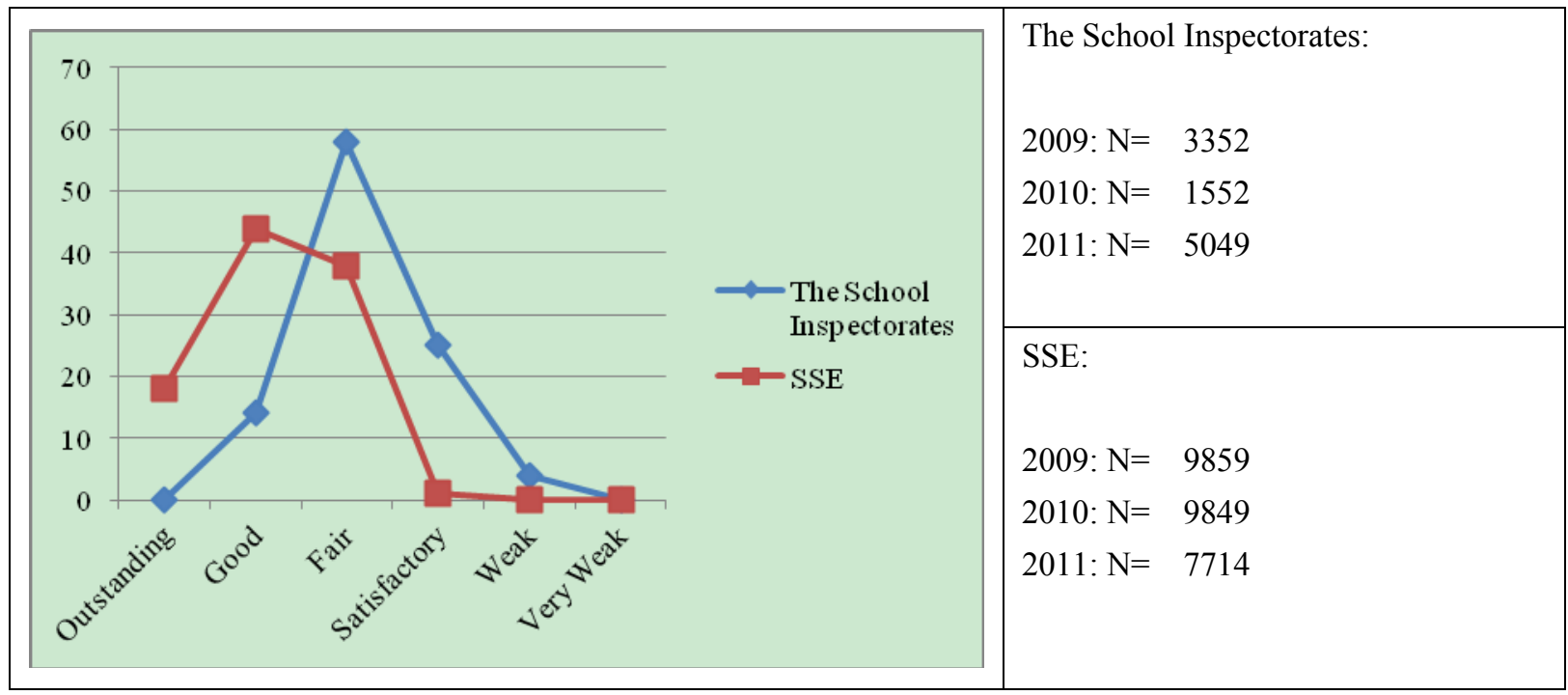

Figure 1. The quality of teaching and learning performance perceived by the school inspectorates compared to SSE (2009-2011)

The big question is what should be done to lessen the gap or difference between SSE conducted by the schools and the Schools Inspectors? Obviously, the verification inspection is done by a group of trained School Inspectors whereas SSE is done by a group of teachers lead by the head teachers. MOE has done a number of efforts in ensuring the success of the implementation of SSE. The Inspectorate of Schools, for example, has conducted a nationwide road show in 2010 to promote SQEM. They targeted not only the administrators in the State and District Education Department but also to all the head teachers. In fact, the Inspectorate of Schools has set up a help centre in every of its state office in order to assist any schools which require any help.

Another alternative of aiding the schools is training on the usage of SQEM 2010. This is also suggested by Blok et al (2008) claiming that intensive training and guidance are important conditions for SSE to be implemented efficiently. It is important to note that teachers are qualified educators but not certified researchers. They obviously need support and guidance to conduct SSE (McNamara et al., 2011). Most importantly, the Inspectorate of Schools has come up with an evaluation instrument which has been revised and adapted according to the current education needs.

The schools are responsible to improve the quality of education in accordance to the needs of their students. For that, they should realise the elements that need to be changed and initiatives that need to be taken. If the schools 
themselves list out the indicators that need to be changed, thus they are accountable to fulfil them in the next SSE. Dubai School Inspection Bureau (DISB), for example, has a different approach for the schools to complete their "Self-Evaluation - A Resource for Schools in Dubai" documents. One of the things the school leaders must do is that they have to list out three areas of performance and three priorities for improvement that can be done by their schools (DISB, 2012). Perhaps MOE should consider this form of reporting to be embedded in its NKRA portal where the schools need to fill up their self evaluation analysis.

With all the promotion efforts and help conducted by School Inspectors, it seems to be lacking of something. Is it attitude? How can it be a part of a school's culture? The question on how to ensure SSE becomes part of a school's culture still remains an enigma (Scheerens, 2004) which is not only faced by Malaysia.

\section{Conclusion}

It is important to note that it is rather difficult to gather information regarding the implementation of SSE in Malaysia perhaps due to a number of reasons. First, it is a challenge to find a scholarly article on SSE in Malaysia. Apart from the MOE official documents and just a few academic theses, research on that matter is practically scarce. Secondly, SSE is strongly associated with MOE's body of inspection. Since the jurisdiction of the Inspectorate of Schools are bound to adhere to confidential restriction as stated in the Education Act 1996, reports of SSE are not allowed to be made public without the Minister of Education's approval.

Reflection of one's worth and value is never an easy to task to partake. There are still a lot more to be done in order to improve the school evaluation process in Malaysia. In the future, if it needs to play its function as a valuable indicator on the quality of education in Malaysia, all the parties involved in SSE have to really ask themselves: Are we doing the right things? Or are we doing things right?

\section{References}

Blok, H., Sleegers, P., \& Karsten, S. (2008). Looking For a Balance between Internal and External Evaluation of School Quality: Evaluation of the SVI Model. Journal of Education Policy, 23(4), 379-395. http://dx.doi.org/10.1080/02680930801923773

Bubb, S., Earley, \& Ahtaridou, E. (2007). The Self-evaluation Form: Is the SEF Aiding School Improvement? Management in Education, 21(3), 32-37. http://dx.doi.org/10.1177/0892020607079991

Coe, R. (2010). School Improvement: Reality and Illusion. British Journal of Educational Studies, 57(4), 363-379. http://dx.doi.org/10.1111/j.1467-8527.2009.00444.x

Creemers, B. P. M., \& Kyriakides, L. (2012). Improving Quality in Education: Dynamic Approaches to School Improvement. Routledge: London.

Croxford, L., Grek, S., \& Shaik, F. J. (2009). Quality Assurance and Evaluation (QAE) in Scotland: Promoting Self-evaluation within and beyond the Country. Journal of Educational Policy, 24, 179-193. http://dx.doi.org/10.1080/02680930902734095

Davidsdottir, S., \& Lisi, P. (2007). Effects of Deliberate Democracy on School Self-evaluation. Evaluation, 13, 371-386. http://dx.doi.org/10.1177/1356389007078628

Demetriou, D., \& Kyriakides, L. (2012). The Impact of School Self-evaluation upon Student Achievement: A Group Randomisation Study. Oxford Review of Education, 38, 149-170. http://dx.doi.org/10.1080/03054985.2012.666032

Devos, G., \& Verhoeven, J. C. (2003). School Self-evaluation: Conditions and Caveats. Educational Management and Administration, 31, 403-420. http://dx.doi.org/10.1177/0263211X030314005

Dubai Schools Inspection Bureau. (2012). Self-evaluation - A Resource for Schools in Dubai. Retrieved August, 2012, from http://www.khda.gov.ae

Emstad, A. B. (2011). The Principal's Role in The Post-evaluation Process - How Does the Principal Engage in The Work Carried Out After Schools Self-evaluation? Educational Assessment, Evaluation and Accountability, 23, 271-288. http://dx.doi.org/10.1007/s11092-011-9128-0

Hall, C., \& Noyes, A. (2009). School Self-evaluation and Its Impact on Teachers' Work in England. Research Papers in Education, 24(3), 311-334. http://dx.doi.org/10.1080/02671520802149873

Hofman, R. H., Dijkstra, N. J., \& Hofman, W. H. A. (2009).School Self-evaluation and Student Achievement. School Effectiveness and School Improvement, 20, 47-68. http://dx.doi.org/10.1080/09243450802664115

Hopkins, D. (2005). The Practice and Theory of School Improvement. The Netherlands: Springer. 
http://dx.doi.org/10.1007/1-4020-4452-6

Jaffer, K. (2010). School Inspection and Supervision in Pakistan: Approaches and Issues. Prospects, 40, 375-392. http://dx.doi.org/10.1007/s11125-010-9163-5

Janssens, F. J. G., \& Amelsvoort, G. H. W. C. H. (2008). School Self-evaluations and School Inspections in Europe: An Exploratory Study. Studies in Educational Evaluation, 34, 15-23. http://dx.doi.org/10.1016/j.stueduc.2008.01.002

Inspectorate and Quality Assurance. (2008). Annual Report 2008. Inspectorate and Quality Assurance, Ministry of Education Malaysia: Putrajaya.

Inspectorate and Quality Assurance. (2009). Annual Report 2009. Inspectorate and Quality Assurance, Ministry of Education Malaysia: Putrajaya.

Inspectorate and Quality Assurance. (2010). Standard KualitiPendidikan Malaysia 2010. Inspectorate and Quality Assurance, Ministry of Education Malaysia: Putrajaya.

Inspectorate of Schools. (2006). Standard for Quality Education in Malaysian Schools: Standard Assurance Instrument. JNS: Putrajaya.

Lander, R., \& Ekholm, M. (2005). School Evaluation and Improvement: A Scandinavian View. In E. D. Hopkins (Ed.), The Practice and Theory of School Improvement. Springer. http://dx.doi.org/10.1007/1-4020-4452-6_5

MacBeath, J., \& Dempster, N. (2009). Connecting Leadership and Learning. Routledge.

MacBeath, J. (2006). School Inspection and Self-evaluation: Working With the New Relationship. London \& New York: Routledge.

MacBeath, J. (2009). Self-evaluation for School Improvement. Second International Handbook of Educational Change. London: Springer.

MacBeath, J. (2006). Self-evaluation: Background, Principles and Key Learning. National College for School Leadership. Retrieved July, 2012, from http://www.ncsl.org.uk

Malaysia. (2010a). Government Transformation Programme. Putrajaya: PEMANDU.

Malaysia. (2010b). Tenth Malaysia Plan. Putrajaya: The Economic Planning Unit.

McNamara, G., \& O'Hara, J. (2008). The Importance of the Concept of Self-evaluation in the Changing Landscape of Education Policy. Studies in Educational Evaluation, 34, 173-179. http://dx.doi.org/10.1016/j.stueduc.2008.08.001

McNamara, G., \& O'Hara, J. (2012). From Looking at Our Schools (LAOS) to Whole School Evaluation Management, Leadership and Learning (WSE-MLL): The Evolution of Inspection in Irish Schools Over The Past Decade. Educational Association Evaluation Accountability. http://dx.doi.org/10.1007/s11092-012-9143-9

McNamara, G., O'Hara, J., Lisi, P. L., \& Davidsdottir, S. (2011). Operationalising Self-evaluation in Schools: Experiences from Ireland and Iceland. Irish Educational Studies, 30, 63-82. http://dx.doi.org/10.1080/03323315.2011.535977

Meuret, D., \& Morlaix, S. (2003). Conditions of Success of a School's Self-Evaluation: Some Lessons of an European Experience. School Effectiveness and School Improvement: An International Journal of Research, Policy and Practice, 14, 53-71. http://dx.doi.org/10.1076/sesi.14.1.53.13867

Ofsted. (2012). Preparing a School Self-evaluation Summary. Ofsted: Manchester.

Penzer, G. (2011). School Inspection: What Happens Next? CfBT: Berkshire.

Plowright, D. (2008). Using Self-evaluation for Inspection: How Well Prepared are Primary School Headteachers? School Leadership and Management, 28, 101-126. http://dx.doi.org/10.1080/13632430801969799

Scheerens, J. (2004). The Evaluation Culture. Studies in Educational Evaluation, 30, 105-124. http://dx.doi.org/10.1016/j.stueduc.2004.06.001

Schildkamp, K., \& Visscher, A. (2009). Factors Influencing the Utilisation of A School Self-evaluation $\begin{array}{lllll}\text { Instrument. Studies in Educational } & \text { Evaluation, 35, }\end{array}$ http://dx.doi.org/10.1016/j.stueduc.2009.12.001 
Schildkamp, K., \& Visscher, A. (2010). The Utilisation of a School Self-evaluation Instrument. Educational Studies, 36, 371-389. http://dx.doi.org/10.1080/03055690903424741

Schildkamp, K., Vanhoof, J., Petegem, P. V., \& Visscher, A. (2012). The Use of School Self-evaluation Results in the Netherlands and Flanders. British Educational Research Journey, 38, 125-152. http://dx.doi.org/10.1080/01411926.2010.528556

Schildkamp, K., Visscher, A., \& Luyten, H. (2009). The Effects of the Use of a School Self-evaluation Instrument. School Effectiveness and School Improvement, 20, 69-88. http://dx.doi.org/10.1080/09243450802605506

Sze, Y. S. Y. (2012). A School Evaluation Policy with a Dual Character: Evaluating the School Evaluation Policy in Hong Kong from the Perspective of Curriculum Leaders. Educational Management Administration and Leadership, 40, 37-68. http://dx.doi.org/10.1177/1741143211420616

Vanhoof, J., Maeyer, S. D., \& Petegem, P. V. (2011). Variation in the Conduct and the Quality of Self-evaluations: A Multi-level Path Analysis. Educational Studies, 37, 277-287. http://dx.doi.org/10.1080/03055698.2010.506326

Vanhoof, J., Petegem, P. V., \& Maeyer, S. D. (2009).Attitudes towards School Self-evaluation. Studies in Educational Evaluation, 35, 21-28. http://dx.doi.org/10.1016/j.stueduc.2009.01.004

Vanhoof, J., Petegem, P. V., Verhoeven, J. C., \& Buvens, I. (2009).Linking the Policymaking Capacities of Schools and The Quality of School Self-evaluations: The View of School Leaders. Educational Management Administration and Leadership, 37, 667-686. http://dx.doi.org/10.1177/1741143209339653

Vanhoof, J., \& Petegem, P. V. (2010). Evaluating The Quality of Self-evaluations: The (Mis)match between Internal and External Meta-evaluation. Studies in Educational Evaluation, 36, 20-26. http://dx.doi.org/10.1016/j.stueduc.2010.10.001

\section{Copyrights}

Copyright for this article is retained by the author(s), with first publication rights granted to the journal.

This is an open-access article distributed under the terms and conditions of the Creative Commons Attribution license (http://creativecommons.org/licenses/by/3.0/). 